\title{
Production and characterization of collagen films containing essential fatty acids for cicatrization
}

\author{
Fernando Mendonça Diz ${ }^{1 *}$, Catharina Grace Santos ${ }^{1}$, Andriele Mendonça Barbosa², Klebson Silva Santos', \\ Lucas Reis d' Costa ${ }^{1}$, Isabelle Souza de Mélo Silva', Clauberto Rodrigues de Oliveira ${ }^{1}$, Juliana Cordeiro Cardoso ${ }^{1}$, \\ Ricardo Luiz Cavalcanti de Albuquerque Júnior ${ }^{1}$, Francine Ferreira Padilha ${ }^{1}$
}

From 5th Congress of the Brazilian Biotechnology Society (SBBIOTEC)

Florianópolis, Brazil. 10-14 November 2013

\section{Background}

The skin is the largest organ of the human body and corresponds to the first line of defense against external aggression. The extent and the commitment of organ and tissue will depend on the severity and intensity of trauma. The regeneration and healing are two processes that compose the restoration of tissues. It is a complex process involving a number of cellular and molecular events, as well as biochemical and physiological phenomena. The process of healing by secondary intention occurs in tissue repair in wounds with a higher degree of injury (injuries that may involve the subcutaneous tissue, muscle or bone). A range of biomaterials have been used in an attempt to incorporate substances that facilitate the process of tissue repair, especially the collagen to be biocompatible and not immunogenic. Essential fatty acids (EFAs) has been used in various types of injuries and different stages of the healing process. Therefore, this study aims to develop, characterize and physically evaluate the effect of collagen films containing EFAs on wound healing of second intention.

The cicatricial part has already generated paper in Acta Cirurgica Brasileira, vol.28 no.5 São Paulo May 2013 (http://dx.doi.org/10.1590/S0102-86502013000500005).

\section{Methods}

The films were produced by the method of casting, where two formulations were prepared using collagen hydrolyzate more commercial EFAs (EFA 50 and 100). The films were characterized by mechanical analysis, macroscopic permeability of water vapor and optical microscopy. For the study of healing surgical wounds were made on the dorsum of 80 rats, covered with films of Collagen (FCOL), collagen films over 50 EFA (FEFA50), and collagen films with EFA100 (FEFA100). Wounds without toppings were used as control (control group). The animals (rats) were euthanized at 3, 7,14, and 21 days. Macroscopic indices of wound contraction (IWC) were obtained and performed histological analysis of the scar area using conventional microscopy and polarized light.

\section{Results and conclusion}

The FEFA50 and FEFA100 films formed transparent, continuous, homogeneous and easy to use. With the addition of EFA50 EFA100 and movies, these had the thickest, stretching, tension and lower Young's modulus. In biological assay (scarring) not macroscopic signs of abscesses or hypertrophic scarring in either group were observed. At 7 days, the IWC observed in FEFA50 was higher compared to the control group, while at 14 days, and FEFA50 FEFA100 these indices showed increased compared to control and movies only COL. FEFA50 FEFA100 and promoted increased neutrophilic infiltration in 3 days, but the lifocítico infiltrate was reduced to 14 days. It was also observed the early development of granulation tissue, reepithelialization of dermal annexes and better collagen organization. This study suggests that films of collagen as an additive containing the essential fatty acids, particularly FEFA50, are promising for use as roofing or wound dressings for dermal enhancement of scar repair process biomaterials.

\section{Acknowledgements}

Authors would like to express their gratitude to CNPq, CAPES and FAPITEC for the financial support and scholarships.

Universidade Tiradentes, Aracaju, Brazil

Full list of author information is available at the end of the article 


\section{Authors' details}

${ }^{1}$ Universidade Tiradentes, Aracaju, Brazil. ${ }^{2}$ Universidade Federal de Sergipe,

RENORBIO, Aracaju, Brazil.

Published: 1 October 2014

\section{References}

1. Magdaleon J, Hatanaka E, Romanatto T, Rodrigues HG, Kuwabara WMT, Scaife C, Newsholme P, Curi R: A proteomic analysis of the functional effects of fatty acids in NIH 3 T3 fibroblasts. Lipids in Health and Disease Jornal 2011, 10: 218.

2. Sánchez-González L, Pastor C, Vargas M, Chiralt A, González-Martínez C, Cháfer M: Effect of hydroxypropylmethylcellulose and chitosan coatings with and without bergamot essential oil on quality and safety of coldstored grapes. Postharvest Biology and Technology 2011, 60: 57-63.

3. Sobral PJA, Monterrey-Quintero ES, Habitante AMQB: Glass transition of Nile tilapia myofibrillar protein films plasticized by glycerin and water. Journal of Thermal Analysis and Calorimetry 2012, 67: 499-504.

doi:10.1186/1753-6561-8-S4-P14

Cite this article as: Diz et al:: Production and characterization of collagen films containing essential fatty acids for cicatrization. BMC Proceedings 2014 8(Suppl 4):P14.

\section{Submit your next manuscript to BioMed Central} and take full advantage of:

- Convenient online submission

- Thorough peer review

- No space constraints or color figure charges

- Immediate publication on acceptance

- Inclusion in PubMed, CAS, Scopus and Google Scholar

- Research which is freely available for redistribution

Submit your manuscript at www.biomedcentral.com/submit
C Biomed Central 